\title{
Beauty and Justice in Modern Pentecostal Theological Themes: No Loggerheads
}

\author{
Dr Kelebogile Thomas Resane (Research Fellow) \\ Department of Historical \& Constructive Theology \\ Faculty of Theology \& Religion \\ University of the Free State, Bloemfontein, South Africa \\ Email: resanekt@ufs.ac.za \\ DOI: https://doi.org/10.46222/pharosjot.1024
}

\begin{abstract}
Historically, Pentecostals associate beauty with worldliness. Quest for power, not purity has been at the core of Pentecostal yearnings. Literature review in this article demonstrates that the wheel has made a 'u-turn' in this regard.. Aesthetics or beauty has become the hallmark of Pentecostal theology. Since the theme is new in the field, a systematic literature review methodology was employed in this study including academic journals, books and websites references as the sources of the research findings. This paper demonstrates that beauty and justice are the themes in the modern Pentecostal theology, and that dogma is experienced rather than just an intellectual exercise. Apologetics is now embraced. Ethics shape morality to make faith attractive. With sacredness of life comes practical holiness, which unfortunately, among the Pentecostals, has led to ascetic and legalistic lifestyle. Justice is the expression of belief and is dogma in action. Sacralisation of space shows how Pentecostals are able to transform spaces into atmosphere that stimulates worship. Beauty and justice are no more themes at loggerheads among the Pentecostals.
\end{abstract}

Keywords: Pentecostal, Justice, Beauty, Dogma, Apologetics, Ethics

\section{Introduction}

Broadly speaking, theological aesthetics examines the relationship of God, faith, and theology to human perception (the imagination and sensation), beauty, and the arts. Historically, Pentecostalism joined Romanticism by revolting against the scientific rationalism of the Enlightenment, which dominated the arts and literature at the beginning of the twentieth century. Pentecostals associated beauty with worldliness. Consequently, beauty was pushed to the margins, which eventually led to aesthetics being understood as the philosophy of the worldly arts. Also, it is very important to note that quest for power, not purity has been at the core of Pentecostal yearnings. New believers are always oriented to rely on charisma. This in some mysterious ways leads to laxity in ethical holiness (Castelo, 2010:88). Since aesthetics is the new phenomenon among the Pentecostals, very little is found in the literature. It is a dynamic phenomenon observable in the public domain. Literature used is mostly on aesthetics from some other Protestant and Roman Catholic perspectives. Personal journeys and current events within the movement justify the dominance of beauty in Pentecostal confessions and kerygmatic activities.

The study involved a traditional literature reviews (TLR) which used in all disciplines including religion. In TLR a research question is selected, various resources from the literature are identified that have information relevant to the question, and the reseracher uses the information from the resources to address the TLR question. The reviews give writers and readers background knowledge, and essentially help them to get up to speed, or help to set the stage for further research which may be conducted on the same or similar themes. 
Pentecostals' origin, since the beginning of the twentieth century (1906), is associated with resistance and rejection of materialism, legalistic dictates and arts without inner spiritual experience. It is for this reason that confessionals and liturgy never had a space in Pentecostal expressions and experience. It can also be observed that there was and still is limitation of icons, statues, and physical symbols as aids towards spiritual connection or expression. Historically, Pentecostals met in a small, simple, and unostentatious buildings which were perceived as a theatron or classroom with no specific architectural specifications. They held to the ancient idea where "Gothic space has been characterized, among other things, dematerialized and spiritualized" (2010:181). The Pentecostal ecclesiology is Augustinian, which understands the church as a community of the faithful people. This community leans on aesthetics as a compelling common source of insight to support its flourishing in the natural world (Lovin \& Mauldin, 2017:114). Pentecostal ecclesiology is intertwined and interwoven by Pneumatology plus Christology. Their ecclesiality is grounded on the presence of Christ and the move of the Holy Spirit. This notion is rooted in Ignatius of Antioch whose dictum was: "Wherever Jesus Christ is, there is the universal church." This is further enhanced by Irenaeus whose dictum was "Wherever the Spirit of God is, there is the church, and all grace" (Kärkkäinen, 2002:83).

The beauty of Pentecostal aesthetics is based on the theological embrace of a pneumatic enthusiasm rather than discursive theology. For Pentecostals, Spirit's experience leads to aesthetic connection with God and self. Experience, rather than rational or mental rhetorics or oratories is at the centre of Pentecostal aesthetics. This differs to Orthodoxy for example, where congregants are essentially a mystical body, who are inspired by the energeia (energy) of the Holy Spirit, and who fall under the headship of Jesus Christ when observing the Holy eucharist and epiklesis praying (Nicolaides, 2010). Thus:

\begin{abstract}
Pentecostalism is associated with religious experience much more than with doctrine and insists on the empowerment - both religious and in everyday life - of the believer through the Holy Spirit (Lamport, 2017:594f).
\end{abstract}

Pentecostal experience is pneumacentric than just ordinary neuro senses. Prayers to the Holy Spirit are basically the plea for the epiklesis of the Spirit (coming of the Spirit) in personal and congregational settings.

The prayer for the Holy Spirit is a plea for the Spirit's all-embracing presence. The Spirit is more than just one of God's gifts among others; the Holy Spirit is the unrestricted presence of God in which our life wakes up, becomes wholly and entirely living, and is endowed with the energies of life (Moltmann, 1997:10-11).

These experiences are realised or experienced as aesthetics (beauty) in doctrinal metanarratives (dogma), apologetics, ethics, sacral space, and social justice.

\title{
Beauty and Dogma
}

For Pentecostal faith, what is believed is to be experienced. Dogma is not a dry knowledge that stimulate thinking patterns, but reality to be experienced even emotively. It is for this reason that when dogma is declared in or to the Pentecostal community, there is a response/reaction of affirmation such as shouting back to the preacher in declarative mood such as 'Amen', 'Hallelujah', 'Praise the Lord' etc. Take an example of attending the Sunday morning worship service, when one declares "Jesus is Lord!" and the uproar from the floor of Amens or Hallelujahs or even Yes. The dogma that 'Jesus is Lord', stirs the inner being and awakens some form of beauty of appreciation. For Pentecostals, dogma is an affirmation of truth, and that truth needs appreciation - whether verbally or in gesticulatory expressions. 
"Pentecostals are convinced that through their doxological experience they encounter the holy triune God" (Castelo, 2010:89). Unpredictable service order marks the gathered Pentecostal service. What stands above is exuberance of the word. Shaull and Cesar explains this exuberance:

The spoken, sung, cried. And murmured word. The pastor is not the only one who speaks. All can express themselves in some way: in hymns, hallelujahs, greeting of the brothers and sisters, testimony, strange tongues, and in choral response to the question shouted out on the speakers, after an affirmation of faith: "Is it or isn't so!?" and the prolonged echo of the congregation: "It is!" (Shaull \& Cesar, 2000:4142).

This exuberance is also captured by Moltmann (2015:24) that "If God is present, the people sing and dance and are carried away by joy. They eat and drink and celebrate the festival of life." God's presence through the Spirit among his people is celebrated by Pentecostals in their gatherings marked by sensationalism, emotionalism, and outbursts of expressions of joy. In another place, Moltmann declares that "If we are seized by his Spirit of life, then an undreamt of love for life awakens in us and our senses are aroused" (2019:31).

It is not just theocentric affirmations that call for response, even anthropocentric affirmations or soteriological annunciations such as "I am washed by the blood of Jesus" will receive some sort of appreciation. Pentecostal soteriology is regarded as the highest experience of encounter with Christ. Hence, experience first, then doctrine. If any doctrinal statements are to be written, they evolve out of personal testimonies and enthusiastic worship encounters (Kärkkäinen, 2002:59). This proves that aesthetically pleasurable experiences are intrinsically worthwhile (Wolterstorff, 2013:222). The most effective witness to the truthfulness and power of the gospel is a changed human life (Castelo, 2012:55).

Pentecostalism is primarily a form of spirituality that has travelled across the globe and adapted itself to various cultural contexts. 'To remain authentic, Pentecostalism must also reflect its original spiritual witness. That witness, that familiarity or communitas cannot be reduced to "text and texture," "style and substance," or even "doctrinal distinctives." It is, rather, a living faith, one that is experienced in community" (Davidsson, 2012:281). Pentecostalism is best understood as a practiced spirituality in which God is the beginning and end of everything (Castelo, 2012:129). Since Pentecostals are beginning to be in touch with the socio-cultural realities their:

proclamational activities synthesised or enthused by the Holy Spirit should address the human misery brought about by the decadent political regimes at hand... The authentic Pentecostal message should lead to the total liberation of humanity from the clutches of evil sociocultural structures. If the message is just for conversion, it will be irrelevant to the human needs in the current South Africa (Resane, 2019:2).

Of great note is that the Acts narrative serves as a basis of dogma for Pentecostal Movement. Their Christology, Pneumatology, Missiology, and Ecclesiology all center around and in the Lukan narrative. In this regard, they are the restorationists, what will commonly be labelled primitivists. And by primitivists, not meaning simple, but their desire is to return to the era of the first century, to re-enact and recapture Book of Acts Christianity.

\section{Beauty and Ethics}


Historically, Pentecostals have viewed their community involvement and organization as being closely related to their church activities. Good examples include initiatives such as outreaches, whereby the church, as opposed to individuals, goes out to be involved in a particular community together as a corporate body.Heeding the biblical command to be "salt and light," Pentecostals have believed that their very presence in the community improved the area. Since the chief reason for being in any community was evangelism, community involvement was often limited to door-to-door witnessing. Churches held events and invited their neighbours as a way to introduce them to church in the hope of converting them. Pentecostal churches seek to preserve their social mission to the community by being visible as a resource of knowledge in areas of evangelism and discipleship. There are many Pentecostal churches that offer more than religious services to their communities; such services usually take the form of informal networks or small "compassion" ministries like food pantries.

One area where Pentecostals share much ground with their evangelical colleagues is the emphasis both put on piety. For Pentecostals, the principle of moral thought with the most theological weight is that which focuses solely on piety or holiness. What defines moral thought for Pentecostals emanates from the Bible, specifically the work of the apostle PaulPentecostals are very Pauline in their outlook on what is moral. The focus on the role of the Holy Spirit's immediate inspiration is also key to Pentecostal ethics. Pentecostals tend to believe that a Spirit-filled person will have the Holy Spirit as his or her internal moral compass for making sound moral and ethical decisions. This has been one reason for the numerous ethical scandals that have plagued Pentecostalism.

The historical roots of Pentecostalism out of Wesleyan Holiness movement bears the reason for experiential holiness they practice as a mark of their sanctification. The piety that has always guided Pentecostal moral theology has not changed over time. Early Pentecostals remained very closely allied with their Holiness counterparts in being suspicious of anything that smacked of worldliness. Pentecostals are very much like many of their Evangelical kin who abhor the intake of alcohol and tobacco smoking. One constantly encounters countless testimonies of people being healed from drinking and from drug abuse, and generally being delivered from morally vacuous behavior such as too much worldly dancing and other amusements. Unfortunately, this led to some ascetic and legalistic dictates, though this has taken a dramatic turn in the recent past. Legalistic dictates included practices that prescribed the types and the sizes of clothes the faithful had to wear. Length of hair, women covering of heads, cosmetics, entertainment (movies, playing cards). Ascetic practices included abstinence from all types of alcohol, eating pork etc. In all aspects of life, Pentecostals emphasized 'holy life' characterized by humility, obedience, and hermitic lifestyle, as friendship with the world is regarded as enmity with God. These practices are regarded as a quest for purity and freedom from worldiness and general materialism.

Principles of moral thought and action for Pentecostals have broadened out beyond those that offend their sense of piety, though piety is still the moral agent with the most value. While some Pentecostals and other evangelicals saw the slow steady accommodation their churches made to popular culture as scandalous (allowing their people to attend movies, sporting events, watching TV, dancing, listening to non-Christian music), nearly all denominations accepted that accommodation as the price of "doing business" with an American culture enthralled with entertainment. Broadening the idea of moral thought or theology beyond piety has been a difficult thing to accomplish. Unless there is a specific biblical example demonstrating that the action is acceptable, such as helping widows and orphans, Pentecostals for the most part have not seen the need to expand their moral universe beyond the internal world of people's thoughts and their socially inappropriate behaviour. Positiveness towards this knowledge is that the metanarratives are used as a guide 
rather than the worldly philosophies that are regarded as being humanistic and materialistic.

One of the most significant shifts in Pentecostalism's character since its inception has been its attitude toward money and possessions. For much of the twentieth century Pentecostals considered "conspicuous consumption" a sin. Sometime in the 1970s things changed. Now most Pentecostals think of financial prosperity as God's blessing. Along with that has come a definite dampening of revival fires among Pentecostals and especially singing and preaching about heaven.

Pentecostals, like most other conservative Christians, such as Roman Catholics and the Eastern Orthodox have very traditional views on both gender and sexuality, taking their cues from particular views of certain biblical passages. Regarding gender, Pentecostals try to mirror what they view as traditional family values. As such, women's roles in Pentecostalism are tightly conscripted to the home and church. Non-traditional roles for women, in the professions or as entrepreneurs, are not discouraged, but they are secondary to a woman's primary role as helpmates to men. Of course due to the rapid changes in socio-economic landscapes, this view has its dissenters; women have leadership roles in churches and other spheres of life. Male gender roles are also tightly conscripted; they are viewed as leaders, providers, and spiritual heads of the household. Pentecostal men and women generally have certain assumptions about their respective roles in the home; both understand what is expected of them, and as such, things once considered taboo, such as divorce and homosexual tendencies or practices are still discouraged. Heterosexual marriage then is extremely important for shoring up these gender roles. Taking much of their ethos about marriage, and the church's role in securing good marriages, Pentecostals regularly offer counselling, invite speakers, and hold conferences around the subject of marriage. Not only is marriage viewed as the most desired outcome of any courtship between men and women, but children are an expectation of any union.

Intertwined in this thinking about gender, and particularly gender roles, is the idea that gender is a physical attribute that is God-given. Sexuality is a gift from God to be enjoyed within the confines of marriage, chiefly for the purpose of procreation. Though such strictures may appear quaint in the contemporary world, great care has been taken to ensure that these same theologically inspired notions do not, like many other traditional mores, become lost in the relativism many Pentecostals believe rules the day. Sexuality and Pentecostalism, particularly homosexuality, has proved to be an intractable issue that has divided churches and families, and has been the underlying cause of some of the more pronounced splits in Pentecostalism. Because of the strong condemnation of homosexuality within most Pentecostal circles, gay and lesbian leaders within the movement have nearly always had to hide their sexual orientation.

The mark of Pentecostal Christianity is an ethical life of sobriety, simplicity, and worshipful attitude. This life, in the Pentecostal worldview is dichotomous... the secular and sacred are clearly definitive and no blurry line exists. It is ecclesiology from above, and therefore employs doctrinal language as common medium of self-understanding that leads to an understanding of the church as the realm of the sacred and the world as the realm of the secular (Haight in Continuum 2004-2008). Life is regarded as a gift of God deserving a complete care attitude, and is also sacred to be protected at all costs. Hence abortion and things like murder of any sort are abhorred.

\section{Beauty and Apologetics}

Initially Pentecostal thought was borrowed largely from the Fundamentalist camp. Their apologetics is largely influenced largely by the Conservative Evangelicals such as William Lane Craig, Ravi Zacharias, Kenneth Samples, Craig Hazen, and Gary Habermas. But there are now a growing number of Pentecostal Apologists who have won respect of the broader 
evangelical community. Notable among this growing community are J.P. Moreland (Philosopher, Biola University) and Fazale Rana (Bio-Chemist). The latter, (Fazale Rana) promotes his apologetics through the organisation called Reason to Believe whose mission is:

to spread the Christian Gospel by demonstrating that sound reason and scientific research - including the very latest discoveries consistently support, rather than erode, confidence in the truth of the Bible and faith in the personal, transcendent God revealed in both Scripture and nature (www.reasons.org.)

Truth in Scripture is totally affirmed by Pentecostals. But because of its emphasis on an experience with the Holy Spirit, truth could also be 'revelatory'. That is, God could reveal something subjectively to a person which was true. Pentecostals were receiving prophecies and words of knowledge from the Holy Spirit which were often found to be a true word from God. Because of Charismatic events in a congregational settings, Pentecostals always feel justified in claiming that God can reveal His truth indirectly to Spirit-filled believers through Scripture and directly by His Holy Spirit.

This new breed of Apologist promotes the use of reason, evidence, logic and scholarly research. They incorporate the latest evidence from cosmology, philosophy, bio-chemistry and astro-physics. But they also affirm the reality of the charismatic gifts described in First Corinthians 12-14. In fact, in his book, "The Kingdom Triangle", Dr J.P. Moreland (2007:14) documents how God's Spirit is demonstrating God's power in a way that is convincing people of the truth claims of Christianity.

Christian Apologetics is about defending the claims of the Bible and giving good reasons to believe in the God of the Bible. For too long many Pentecostals have shunned or even ridiculed Evidential Apologetics (giving a coherent picture of truth in support of Scripture). Without being able to put a label on it, many Pentecostals would actually favour Presuppositional Apologetics. Ironically even those who reject Evidential Apologetics in favour of Presuppositional Apologetics (the belief that unless God has already opened the heart of the unregenerate no amount of evidence will ever persuade them) have their reasons for saying that reasons are not necessary. In a moment I'm going to argue for Presuppositional Apologetics in concert with Evidential Apologetics.

People believe the claims of the Bible for different reasons. Some accept the claims of the Bible because the evidence from history, science, philosophy, and logic comports with it. Others believe it for social reasons - they have observed a genuine conversion or genuine follower of Christ and attracted to Christ as a result. Others believe because they witness a miracle - the miracle acts a sign and a wonder. Others believe because they experience an undeniable miracle at some point in time. This was the case with the Saul of Tarsus who vigorously denied the claims of Christ and His Christians but then experienced a miracle encounter with this Christ.(Acts 9:1-9; 22:1-11; 1 Timothy 1:12-14)

When the Fundamentalist Christian does apologetics they have the problem of presenting an incoherent picture of truth - that is, they cannot integrate the truth of science, philosophy, history, with their interpretation of Scripture. When the Evangelical does apologetics they have the problem of largely basing their appeal to reason or social persuasion. But the Pentecostal, who takes the best of Evangelical reasoning, is able to present a coherent picture of truth with the potential for the added dimension of supernatural confirmation (Shaull \& Cesar, 2000:11).

These Pentecostal Apologists often challenge those ideas within Pentecostalism which frequently make defending the claims of the Bible difficult (especially with a more sophisticated audience). In the crosshairs of this type of challenge is the very nature of truth. It has been 
said that the Protestant movement was a Bible-based movement while the Pentecostal movement has been a Spirit-based movement (Shaull \& Cesar, 2000:11).

Theologically, most Pentecostal denominations are aligned with Evangelicalism in that they emphasize the reliability of the Bible and the need for conversion to faith in Jesus. While there is a cross-pollination with other movements, Pentecostals differ from Fundamentalists by placing more emphasis on personal spiritual experiences (often emotional), and, in most cases, by allowing women into the ministry.

\begin{abstract}
Pentecostals embrace a transrational worldview. Although Pentecostals are concerned with orthodoxy ("correct belief"), they are also concerned with orthopathy ("right affections") and orthopraxy ("right reflection or action"). Reason is esteemed as a valid conduit of truth, but Pentecostals do not limit truth to the realm of reason (http://www.wordiq.com/definition/Pentecostal).
\end{abstract}

A new generation of Pentecostal Apologists is challenging this concept of truth. Unlike Evangelicals or Fundamentalists who generally dismiss claims of Charismatic phenomena, these emerging Pentecostal Apologists put such claims to the test. They take very seriously the Biblical injunction of 1 Thessalonians 5:19-21 - Do not quench the Spirit. Do not despise prophecies, but test everything; hold fast what is good.

There is no doubt that these days, Pentecostals are becoming serious and conscious about rational thinking when coming to theological discourse. They however remain insistent that the world sicknesses and demonic activities need to be addressed aggressively; and that signs and wonders remain the hallmark of their evangelistic and discipleship activities.

The resultant denial of the supernatural has crippled much of theology, leading to at least two serious consequences. First, most present-day Western systematic and pastoral theologies fail to address the demonic at both the personal and cosmic levels ... The other consequence is that Western Christians often fail to fit the 'signs and wonders' of the Holy Spirit into their theological framework... (Yung, 2010:4).

This emerging Pentecostal Apologetics values logic, reason, philosophy, history, sciences, and the inerrancy of Scripture. But they have also learned to incorporate a divinely supernatural dimension to their presentation (Ruthven, 1996:3). This begins in their own soul where they experience an empowering from the Holy Spirit subsequent to their conversion. It continues as they learn to discern the Holy Spirit's leading. It is developed as they walk in faith by praying for the sick and speaking words of knowledge. And it is undergirded as they pray in the Spirit for the God of Miracles to reveal Himself in supernatural ways to those who believe.

For Pentecostals, apologetics is built around a question: "Why do some people believe?" The Pentecostal faith is a narrative of conversion, or a story of a journey from atheism to belief in the God of the Bible because of the evidence (Vondey, 2012:1). For instance, for some, it may be for example their conversion story from Islam to Christianity, from witchcraft to Christian practice. A former homosexual's story may be his conversion to Christianity was based on the love and acceptance he experienced in a Christian community. Many people become Christians for reasons like these, but, by far, the most common reason, at least statistically, is some kind of Pentecostal encounter. Pentecostalism was born as a reaction from stale and unappealing faith. There was a loss of wonder that led to despair for many people. Faith in Christ is not cheap, and therefore needs to be defended. Unfortunately this is done out of experience or historical events that are often extra-biblical in nature. However, the beauty of 
Pentecostal faith is that the major tenets of Christian faith such as the deity of Jesus Christ, his death, resurrection, and return in glory are some of the fundamental pillars of faith not to be subjected to any form of criticism or scrutiny. All the orthodox doctrines are the sacrosanct metanarratives are not to be tampered with in any sense.

Why is Apologetics important for Pentecostals, especially in Africa? It's time now to realise that in the West, more people are walking away from Christianity than are joining it. Why are they walking away from belief in the God of the Bible? Firstly, Christianity has been presented in an incoherent manner to them. They cannot integrate faith and reason. They see the Bible and science as contradictory to what churches teach. Secondly, their experience of Christianity was supernaturally unsatisfying for some reason. Conversion to Christ was presented to them as a purely intellectual enterprise. Prayer was dismissed and relieved of its supernatural potential. Miracles were relegated to only a by-gone era.

Apologetics is therefore necessary to go some of the way to stemming the tide of Christian decline. Since Pentecostals form the emerging majority of Christians the need for Pentecostal Apologetics is all the more urgent because in the coming years a new generation of Pentecostals will be exposed to the onslaught of unprecedented intellectual attacks upon their faith. This is why we need a new breed of Pentecostal Apologists who can give a reasoned defence of the faith in the God of the Bible complemented by a demonstration of the Spirit's power.

The kind of Pentecostal apologist called for now, is one who is grounded in the classic reasoning for Christianity, both theologically and philosophically. A Pentecostal apologist is faced with a challenge to become conversant with the belief systems of the world's major religions; and of course qualified in the art and science of Hermeneutics. This is the mammoth task as it calls for the Pentecostal apologist to be able to integrate the record of nature with the record of Scripture in a coherent fashion (Corbett, 2010:6). This ability to state facts should be intertwined with some vivacious living relationship with Jesus Christ through the infilling of the Holy Spirit; after all when the angel explained to Mary how she would bear Jesus Christ: "The Holy Spirit will come upon you, and the power of the Highest will overshadow you; therefore, also, that Holy One Who is to be born will be called the Son of God" (Luke 1:35). Mary does not hesitate, but actively seeks to choose to serve and obey God and to do His will and we also should thus be guided by the infilling of the Holy Spirit (Nicolaides, 2014). The apologist should be persuaded of the reality of the charismatic expression of the Holy Spirit's gifts for today. This is a call for such a breed of Pentecostal Apologists who can demonstrate the power of 'Pentecostal' Apologetics who are bold enough to step out wisely in faith as a conduit for the power of the Holy Spirit to demonstrate His miraculous power and grace (Corbett, 2010:5).

Pentecostalism has come to realisation that a method based primarily upon reason and apologetics is increasingly dissipating in favour of one that seeks to answer the question: "How is your living faith, how has your encounter with God something that ought to be meaningful for me?" Apologetics must be reframed(Corbett, 2010:5).

\section{Beauty and Sacralisation of Space}

Pentecostals emphasize the visual in their practices and in their visual culture. It is only half a century ago that Pentecostals started to seriously consider the beauty of the worship space. Visual and the acoustic (sight and sound) occupy a central place in Pentecostal and Charismatic experiences of the numinous (Pype, 2015:359). There is an ongoing exodus from the tiny country church to a massive auditorium with some tainted glasses, special lights, colours' that merge, and glossy furniture items, including soft seats/sofas that make congregants very comfortable. Entering any space of Pentecostal worship, one is confronted with stage décor, especially curtaining or some form of symbols reflecting the vision, mission, 
and core values of the local assembly. Berenson claims that it is within the human nature that when a great artwork is seen, there is a feeling of emotional thrill of transfiguring sensation (1902:124). In another place, Berenson (1930:136) reinforces this fact that 'When the viewer looks at a tactile work, his or her life gets and extra surge of force'. Resane (2018:4) correctly highlights the fact that "If the symbols or monuments were properly interpreted from the religious perspective, they would make God real and fathomable." It is clear that beauty is something seen, and when seen, emotions are evoked. This leads to some emotional outburst e.g. crying, bubbling with praise or appreciation. Beauty in worship space enables spiritual connection since the symbols present recharge the atmosphere. Castelo points out that Pentecostalism is an 'epicletic community', hence, they privilege worship as a way of securing authority and truth claims; and doxology as a modality of knowledge and being (Castelo, 2012:130).

\section{Justice as Expression of Beauty}

In recent years, the Pentecostals have started to appreciate that the proclamation of a "full gospel" includes not only evangelism (as traditionally) understood, but also a social dimension (Clifton \& Omerod, 2007:230-231). Wolterstorff correctly points out that justice characterizes our social relationships insofar as we are treated as we have a right to be treated (2013:222). Like all other branches of Christianity, Pentecostalism is concerned about the Christian commitments to social justice and the conservation of creation (Vondey, 2012:1). They have been striving to dislocate themselves from the historical criticism labeled by their contemporary fundamentalists. Their swing towards holistic evangelism and discipleship was viewed with suspicion by fellow evangelicals. Ruthven (1996:2) points out how the early Pentecostals strove to be accepted within the fold:

To gain acceptance, Pentecostals desperately tried to behave and believe more fundamentalist than the fundamentalists, but mostly they received rejection for their efforts. Nevertheless, classical Pentecostals fervently shared the fundamentalist refrain: 'My hope is built on nothing less Than Scofield's notes and Moody Press!

Justice is noticeable in Pentecostal preaching as a homiletic event that emphasizes action and performance. Pentecostal eschatological expectations that was parochial towards heaven alone has now become an emphasis on change, transformation where praxis is the climax. It still maintains that "Human acts of change function as vehicles for practical witness: fides quaerens actum" (Louw, 2016:2). In other words, acts of justice are to be biblically authentic in order to be practised. By fides quaerens imaginem, Louw points out that the iconic and aesthetic dimension of preaching is hopeful and faithful 'seeing'; preaching as deciphering of meaning and destiny of life by means of symbolising and imaging. The discovery of 'beauty' becomes an event in itself, a kind of homiletic happenstance; life is 'beautiful' and 'hopeful', hence, the emphasis on preaching as a deeply spiritual and iconic event should be practical. Although Louw is not referring to the Pentecostals here, the application seems to be more of what Pentecostals will assert and tend to embrace.

In South Africa, Pentecostal centennial existence, especially the Whites, was marked with docility and passiveness, generally by their briller par son absence from socio-political activities, in matters relating to social justice (Resane, 2018:3). They encouraged their Black adherents to do the same, as politics were deemed as having evil roots and worldly intentions that may make one miss heaven.

White Pentecostals were, except for a few voices, generally passive towards racial segregation. The policies of the apartheid state 
protected their comfort zones and their supremacist egos of preserving their European-ness and ethnic identity (Resane, 2018:4).

The wheel has, however, turned around. Beauty and justice are not at loggerheads as they were a few decades ago in the Pentecostal movement. Pentecostals, both classical and neocharismatics, have started to demonstrate that kerygma, aesthetics, and justice are indivisible. The beauty of preaching is to be substantiated with unpretentious activism in social structures where justice is called for. The South African socio-political landscape demands some prophetic authenticity that walks with two feet of beauty and justice. The sense of the value of life among the Pentecostals has a very high bar not to be jumped willy-nilly. Humanity is regarded by Pentecostals as a sacred creation to be respected and accepted without any reservation. Pentecostals, especially, the Neo-Charismatics constantly conscientise us to the notion that every space is indeed a sacred space. They go beyond civic by-laws by starting churches in buildings that are not officially designated as worship centres. One finds their worship services in hotels, shopping complexes, industrial warehouses, cinemas, community centres such as halls, orphanages, schools, and significantly, of late old church buildings (mostly historically white), that had become dilapidated or abandoned due to demographic changes. "The flight of the white people from the city centres affected the church. White church buildings and religion became redundant" (Resane, 2019:6).

In the postmodern era, Pentecostals are coming back to the right senses of embracing the incarnational ministry of Jesus Christ. They realise that proclamation without service is biblically null and void.

If service is not an integral part of gospel proclamation, the proclamation is empty... Performed in the right way, service and witness constitute a programme of restoration, of reconciliation and healing, culminating in 'fellowship with us', God and fellow human beings. The served are saved and the saved serve (Mathema, 1995:60).

\section{Conclusion}

Indeed, there is some beauty in Pentecostal theology. The 'wheel has turned around' somewhat now. Pentecostals that were once considered socially irrelevant and politically naïve are now transforming. Some have shifted from an apolitical stance in their witness. There should be an acknowledgement that the ultimate goal has not yet been reached, but there is still hope. Historically, Mochechane is correct that the problem of the Pentecostals, including Charismatics has been trying to operate in socio-political vacuums. They go about daily action as if they live in heaven with their feet removed from the ground and heads hidden up in the clouds, except where money is concerned. This status quo is changing as this paper points out. Many Pentecostal adherents are coming to the realisation that "no theology can be done in a socio-political vacuum" (Mochechane, n.d:262).

Beauty and justice sounded oxymoronic among the Pentecostals, now their theological praxis is embracing justice in all its angles, since now the full gospel is not only proclamation without incarnation. They have demonstrated fervour for missions globally. Appreciation of a new life in Christ as a result of conversion is seen to be bearing fruit in the public domain. They are still invited to engage in acts of structural liberation. Like many evangelicals, of which the Pentecostals are part, natural and social justice has become an expression of the inner work of the Holy Spirit. The awakened spiritual gifts contribute towards a mobilisation for service to Christ and the communities, as they continue to deal with the forces of darkness and wickedness that beleaguer their communities. Pentecostals have joined the socially concerned community formations in medical, educational, poverty alleviation, social upliftment endeavours etc. to authenticate their responsive "Praise the Lord" , Amen!", "Hallelujahs!" 
slogans when people's lives are changed, not only spiritually, but also socio-economically. Mathole rightly points out that they are:

Now faced with contextual realities characterised by issues such as poverty, HIV/Aids, and moral degeneration. They have to deal with these serious and complex issues - if they are to be authentic heralds of the gospel. When faced with such serious social problems they do not have the luxury of being apathetic as they were during the apartheid period (Mathole in Kretzschmar \& Ntlha, 2005:36).

Beauty and justice are no more marriage partners at loggerheads among the Pentecostals. Pentecostals have become inclusive in their diaconical and kerygmatic activities. They embrace aesthetics in theology and realise that there is some beauty in doctrinal beliefs and confessions.

\section{References}

Berenson, B. (1902). The central Italian painters of the renaissance, 4th Impression. New York, G.P Putnam's Sons Press.

Berenson, B. (1930). The Italian painters of the renaissance, rev. edn. Oxford, Clarendon Press.

Castelo, D. (2010). "The Improvisional Quality of Ecclesial Holiness" in Toward a Pentecostal Ecclesiology: The Church and the Fivefold Gospel, ed. John Christopher Thomas. Cleveland, CPT Press.

Castelo, D. (2012). Revisioning Pentecostal Ethics: The Epicletic Community. Cleveland, CPT Press.

Clifton, S \& Ormerod, N. (2007). "Pentecostals and Politics". Asian Journal of Pentecostal Studies, 10(2), $229-244$.

Corbett, A. (2010). The Power of Pentecostal Apologetics, 3rd November 2010 https://www.findingtruthmatters.org/articles/apologetics/pentecostal-apologetics-defendingthe-gospel-with-power/ (Visited 29 August 2019).

Davidsson, T.H. (2012). Lewi Pethrus' Ecclesiological Thought 1911-1974: A

Transdenominational Pentecostal Ecclesiology. PhD Diss., University of Birmingham.

Haight, R. S.J. (2004). Christian Community in History: Comparative Ecclesiology. 3 vols. New York, Continuum, 2004-2008.

Kärkkäinen, V. (2002). Toward a Pneumatological Theology: Pentecostal and Ecumenical Perspectives on Ecclesiology, Soteriology, and Theology of Mission. Maryland, University Press of America.

Lamport, M.A, ed. (2017). Encyclopedia of Martin Luther and the Reformation, Vol 2. Lanham, Maryland, Rowman \& Littlefield.

Louw, D.J. (2016). 'Preaching as art (imaging the unseen) and art as homiletics (verbalising the unseen): Towards the aesthetics of iconic thinking and poetic communication in homiletics', HTS Teologiese Studies/ Theological Studies, 72(2),, a3826. http://dx.doi. org/10.4102/hts.v72i2.3826 
Lovin, R.W \& Mauldin J. (2017). Theology as Interdisciplinary Inquiry: Learning with and from the Natural and Human Sciences. Grand Rapids, W.B. Eerdmans Publishing Company.

Mathema, Z.A. (1995). "A Response to 'Service and Witness' in African Church in the 21st Century: Challenges and Promises, ed. D.W. Waruta. Nairobi: All Africa Conference of Churches.

Mathole, E. (2005). 'Pentecostal-Charismatic evangelicalism: Lessons learnt and the way forward" (pp 32-42), in Looking back, Moving forward: Reflections by South African Evangelicals, eds. Louise Kretzschmar and Moss Ntlha. Johannesburg: The Evangelical Alliance of South Africa.

Mochechane, S. (n.d.). Bhengu and Pan Africanism: Running with the Horses. Lambert Academic Publishing.

Moltmann, J. (1997). The Source of Life: The Holy Spirit and Theology of Life. Minneapolis, Fortress Press.

Moltmann, J. (2015). The Living God and the Fullness of Life. Louisville, Westminster John Knox Press.

Moltmann, J. (2019). The Spirit of Hope: Theology for a World in Peril. Louisville, Westminster John Knox Press.

Nicolaides, A. (2010). The Laos tou Theou - an orthodox view of the "people of God", HTS Teologiese Studies/Theological Studies, 66(1), DOI: 10.4102/hts.v66i1.372

Nicolaides, A. (2014). The philosophical conception of Mariology and the notion of Theotokos in the teachings of Saint Ambrose. Phronimon, 15(2), 18-37.

Pype, K. (2015). "The Liveliness of Pentecostal/Charismatic Popular Culture in Africa" (345378) in Pentecostalism in Africa: Presence and Impact of Pneumatic Christianity in Postcolonial Societies. Leiden, Netherlands, Koninklijke Brill..

Resane, K.T. (2018). Pentecostals and apartheid: Has the wheel turned around since 1994?, In die Skriflig,52(1), a2259. https://doi. org/10.4102/ids.v52i1.2324

Resane, K.T. (2018). Statues, symbols and signages: Monuments towards socio-political divisions, dominance and patriotism?, HTS Teologiese Studies/ Theological Studies, 74(1), 4895. https://doi.org/ 10.4102/hts.v74i4.4895.

Resane, K.T. (2019). Church in Society: The Pentecostal Church in Action, Pharos Journal of Theology ISSN 2414-3324 online,100 - (2019) Copyright: @2018 Open Access/Author/s Online @ http//: www.pharosjot.com1

Resane, K.T. (2019). Demographic change: Ecological and polycentric challenges for white Christianity in urban South Africa, HTS Teologiese Studies/Theological Studies, 75(1), a5266. https://doi.org/ 10.4102/hts.v75i1.5266

Ruthven, J.M. (1996). "Back to the Future for Pentecostal/Charismatic Evangelicals in North America and World Wide: Radicalising Evangelical Theology and Practice." Regent University School of Divinity. https://www.hopefaithprayer.com/books/Back-Future-for-PentecostalCharismatic-Evangelicals-Ruthven.pdf (Visited 23 August 2019).

Shaull, R \& Cesar, W. (2000). Pentecostalism and the Future of the Christian Churches: Promises, Limitations, Challenges. Grand Rapids, W.B. Eerdmans Publishing Company.

Sheldrake, P. F. (2010). Explorations in Spirituality: History, Theology, and Social Practice. New York, Paulist Press. 
Vondey, W. (2012). The Unity and Diversity of Pentecostal Theology: A Brief Survey for the Ecumenical Community of the West.

https://www.academia.edu/36267400/The_Unity_and_Diversity_of_Pentecostal_Theology_A _Brief_Survey_for_the_Ecumenical_Community_of_the_West (Visited 23 August 2019).

Wolterstorff, N. P. (2013). Journey Towards Justice: Personal Encounters in the Global South. Grand Rapids, Baker Academic Books.

Yung, H. (2010). "A 21st Century Reformation: Recover the Supernatural" http://www.christianitytoday.com/globalconversation/templates/article_print.html?id=89334 (Visited 23 August 2019)

- http://www.wordiq.com/definition/Pentecostal (Visited 8 August 2019). Page removed from the website since last visited. 